\title{
First Report of Lignin Peroxidase Production from Alternaria alternata ANF238 Isolated from Rotten Wood Sample
}

\author{
Anuja Sharma ${ }^{1}$, Neeraj K. Aggarwal ${ }^{1, *}$, Anita Yadav $^{2}$ \\ ${ }^{1}$ Department of Microbiology, Kurukshetra University, India \\ ${ }^{2}$ Department of Biotechnology, Kurukshetra University, India
}

Copyright $\bigcirc 2016$ by authors, all rights reserved. Authors agree that this article remains permanently open access under the terms of the Creative Commons Attribution License 4.0 International License

\begin{abstract}
Lignin peroxidases are considered to be the primary enzyme for oxidative depolymerisation of lignin and are responsible for $\mathrm{H}_{2} \mathrm{O}_{2}$-dependent oxidation of both phenolic aromatic substrates and non-phenolic lignin model compounds. The present study was undertaken to study the production of Lignin peroxidase enzyme by Alternaria alternata ANF238 isolated from rotten wood sample using water hyacinth as a lignocellulosic substrate under solid state fermentation. Various production parameters like initial moisture content, various carbon sources, nitrogen sources, inducers and their concentrations were also optimized to further increase the production of this enzyme. Maximum lignin peroxidase yield of $7.6 \mathrm{U} / \mathrm{g}$ of dry substrate was obtained with water hyacinth as substrate supplemented with $0.5 \%$ mannitol as carbon source, $1 \%$ ammonium sulphate as nitrogen source and $3 \mathrm{mM} \mathrm{MnSO}_{4}$ as inducer under optimized conditions. These results indicate that Alternaria alternata ANF238 is a potential candidate for production of lignin peroxidase using solid state fermentation, an enzyme with wide industrial and biotechnological applications. This study also promises effective utilization of water hyacinth as a substrate for lignin peroxidase production. To the best of our knowledge, this is the first report on LiP production by Alternaria alternata.
\end{abstract}

Keywords Alternaria alternata, Eichhornia crassipes, Lignin Peroxidase, Lignolytic Enzymes

\section{Introduction}

Lignin is a cementing, tough noncarbohydrate polyphenolic structural constituent of cell wall of all the vascular plants, interspersed with the hemicelluloses and thus keeping cellulose locked within structural confinements of cell wall. Due to the significance of the lignocellulosic biomass as a renewable resource for the production of biofuel, research on the fungal degradation of lignin has gained intense attention. It is highly resistant to microbial degradation due to its extensive crosslinking between its polyphenolic constituents and biologically stable ether linkages [1]. Two major families of lignolytic enzymes involved in the enzymatic degradation of lignin are phenol oxidase (laccase) and peroxidases (lignin peroxidase, LiP and manganese peroxidase, MnP) [2]. Laccase (EC 1.10.3.2 benzenediol: oxygen oxidoreductase), catalyses the oxidation of phenolic compounds while concomitantly reducing molecular oxygen to water [3, 4]. It can also oxidize nonphenolic aromatic compounds as well as $\mathrm{Mn}(\mathrm{II})$ in the presence of primary substrates. MnP [EC 1.11.1.13, $\mathrm{Mn}(\mathrm{II})$ :hydrogen-peroxide oxidoreductase, $\mathrm{MnP}$ ] catalyzes the oxidation of $\mathrm{Mn}(\mathrm{II})$ to $\mathrm{Mn}(\mathrm{III})$, which in turn oxidizes a variety of phenolic dyes and phenolic lignin model compounds. Lignin peroxidases [EC 1.11.1.14, 1, 2-bis(3,4-dimethoxyphenyl)

propane-1,3-diol:hydrogen-peroxide oxidoreductase] are relatively nonspecific, have high redox potential and are responsible for $\mathrm{H}_{2} \mathrm{O}_{2}$-dependent oxidation of both phenolic aromatic substrates and non-phenolic lignin model compounds $[1,5,6]$. Out of these enzymes, lignin peroxidase plays a very important role and is also considered to be the primary enzyme for oxidative depolymerisation of lignin by its long range electron transfer pathway [7]. Due to its nonspecific substrate specificity it has potential in treatment of industrial effluents and xenobiotics [8], decolorization of dyes [9], degradation of dyes and distilleries [10, 11]. LiP was first discovered in Phanerochaete chrysosporium, and various isoforms are known to exist with this microorganism and also a number of other white-rot fungi $[12,13]$.

Various studies on the potential of microorganisms to degrade lignin have shown that white rot fungi are the most efficient lignin degraders [14]. Thus most of the research concerning biodegradation of lignin has been centered on white rot fungus and $P$. chrysosporium is considered to be the model organism for the study of the lignolytic-enzyme 
production system [15]. However, reports of these lignolytic enzymes being produced from other fungi like Aspergillus, Fusarium, Penicillium, Alternaria and Rhizopus are also available [16-21].

Eichhornia crassipes, an aquatic plant is one of the world's most noxious weeds due to its rapid proliferation rate, growth in extreme environmental conditions and its impact on environment and ecological communities. Strategies including physical removal, chemical methods and biological control agents have proven inefficient for complete eradication of Eichhornia crassipes because of various environmental and financial factors associated with these methods. On the other hand, water hyacinth, due to its low lignin content is a rich source of lignocellulosic biomass and has also been exploited as a raw material in various useful applications and thus its management by large scale utilization is an attractive approach [22, 23].

Alternaria alternata has previously been studied for its lignin degrading ability but only few studies reported production of lignolytic enzymes [24-26]. A.M. Mabrouk [27] demonstrated laccase production from A. alternata isolated from marine algae Pterocladia $s p$ under nitrogen limiting condition but no MnP or LiP activity was detected. There are no reports till date on the production of LiP from Alternaria alternata. The present study was undertaken to study the production of Lignin peroxidase enzyme by Alternaria alternataANF238 isolated from rotten wood sample using water hyacinth as a lignocellulosic substrate. Also the effect of initial moisture content, various carbon sources, nitrogen sources, inducers and their concentrations on LiP production was studied by conventional "one factor at a time" approach. To the best of our knowledge, this is the first report on LiP production by Alternaria alternata.

\section{Materials and methods}

\subsection{Lignocellulosic Biomass}

Water hyacinth was collected from a pond heavily infested with water hyacinth and located in Jyotisar, Kurukshetra. Only shoots and leafy parts of the plant were used to prepare biomass. While collecting the plant it was taken into consideration that the plant was not dry or infected. It was washed under tap water, chopped in to small pieces $(1-2 \mathrm{~cm})$, dried at $70^{\circ} \mathrm{C}$ till constant weight and was ground into fine powder for further use. Biomass of particle size $0.3-0.4 \mathrm{~mm}$ was used in all the experiments.

\subsection{Isolation of ANF238}

Isolate no. ANF238 (Alternaria alternata) was isolated from rotten wood sample collected from Kurukshetra University, Kurukshetra. Isolation was done using enrichment culture technique. $1 \mathrm{~g}$ of rotten wood sample was suspended in $50 \mathrm{ml}$ of basal medium [28] containing $1 \%$ water hyacinth biomass as the sole carbon source and incubated at $25^{\circ} \mathrm{C}$ at $130 \mathrm{rpm}$ for 7 days. After $4-5$ transfers in fresh medium, serial dilutions were prepared in normal saline solutions $(0.85 \% \mathrm{NaCl})$ and plated on agar plates with same composition as enrichment medium. Pure fungal cultures were obtained by subsequent transfers to fresh lignin agar (basal medium with $0.1 \%$ lignin) plates.

\subsection{Identification}

Initial identification was done using microscopic observation after lactophenol cotton blue staining. Features like conidia and their shape and arrangements, conidiophore, hyphae were observed. The organism was further characterized at Eurofins Genomics India Pvt Ltd. Bangalore; Karnataka, India using 28S rRNA based molecular methods. Forward and reverse DNA sequencing reaction of PCR amplicon was carried out with 28SF and 28SR primers using BDT v3.1 Cycle sequencing kit on ABI 3730xl Genetic Analyzer Consensus sequence of $28 \mathrm{~S}$ rRNA gene was generated from forward and reverse sequence data provided using aligner software. The $28 \mathrm{~S}$ rRNA gene sequence was used to carry out BLAST with the nrdatabase of NCBI genbank database. Based on maximum identity score first ten sequences were selected and aligned using multiple alignment software program Clustal W. The evolutionary history was inferred using the Neighbor-Joining method [29]. Distance matrix was generated using RDP database and the phylogenetic tree was constructed using MEGA 4 [30].

\subsection{Primary Screening}

Lignin peroxidase production was initially confirmed by azure B dye decolorization plate assay in which a clear zone around the fungal colony was obtained after 7 days of incubation on azure $\mathrm{B}$ agar medium containing $0.1 \%$ $\mathrm{KH}_{2} \mathrm{PO}_{4}, 0.05 \% \mathrm{NH}_{4} \mathrm{NO}_{3}, 0.05 \% \mathrm{MgSO}_{4} .7 \mathrm{H}_{2} \mathrm{O}, 0.001 \%$ $\mathrm{FeSO}_{4} .7 \mathrm{H}_{2} \mathrm{O}, 0.001 \% \mathrm{MnSO}_{4} \cdot \mathrm{H}_{2} \mathrm{O}, 0.01 \%$ Yeast extract, $0.001 \% \mathrm{CaCl}_{2} .7 \mathrm{H}_{2} \mathrm{O}, 0.001 \% \mathrm{Cu} \mathrm{SO}_{4} .5 \mathrm{H}_{2} \mathrm{O}$ and $.01 \%$ azure B.

\subsection{Inoculum Preparation}

The organism was grown on 5 different media including Potato Dextrose Agar (PDA), Potato Dextrose Yeast Agar (PDYA), Czapeck Dox agar (CDA), Malt Extract Agar (MEA), Sabouraud Dextrose Agar (SDA) for 7 days. The media on which the maximum growth was obtained was further used for culture maintenance at $4^{\circ} \mathrm{C}$ and inoculum preparation for enzyme production. The inoculum was prepared on Agar plates of the selected medium incubated at $25^{\circ} \mathrm{C}$ for 7 days and $8 \mathrm{~mm}$ fungal disc was used as inoculum for enzyme production.

\subsection{Enzyme Production}

Enzyme production was observed under solid state fermentation in $50 \mathrm{ml}$ Erlenmeyer flasks containing $2 \mathrm{~g}$ water 
hyacinth biomass. Basal medium as described by M. Tien and T.K. Kirk [5] was used to attain desired initial moisture level. Initial $\mathrm{pH}$ of the medium was set at 4.5. The media was inoculated with two $8 \mathrm{~mm}$ disc and incubated at $35 \pm 2^{\circ} \mathrm{C}$ and lignin peroxidase production was studied for 30 days. For enzyme extraction $10 \mathrm{ml}$ of $0.5 \mathrm{M}$ acetate buffer $(\mathrm{pH}=5.0)$ was added, after which the culture was filtered through muslin cloth and centrifuged at $10,000 \times \mathrm{g}$ for $30 \mathrm{~min}$ at $4^{\circ} \mathrm{C}$. The supernatant was filtered through Whatman no. 1 filter paper and assayed for lignin peroxidase activity. Effect of initial moisture content, various carbon sources, nitrogen sources, inducers and their concentrations on laccase production was studied.

\subsection{Optimization of Cultural Parameters for Lignin Peroxidase Production}

Various cultural parameters affecting production of lignin peroxidase during solid state fermentation were optimized. The tested parameters in the present study were incubation time, Initial moisture content $(50,100,150,200,250$, and $300 \%$ ), carbon sources (Glucose, Fructose, Sucrose, Lactose, Mannitol, and Starch), nitrogen sources (Ammonium sulphate, Ammonium nitrate, Peptone, Tryptone, Urea and Yeast extract) and inducers $\left(\mathrm{CuSO}_{4}\right.$, Gallic acid, Guaiacol, $\mathrm{MnSO}_{4}$, Tween 80, Veratryl alcohol).

\subsection{Enzyme Assay}

Lignin peroxidase activity was determined by the method described by F.S. Arachibald [31]. This method is based on the oxidation of dye azure B. The reaction mixture $(1 \mathrm{ml})$ contained $50 \mathrm{mM}$ sodium tartrate buffer $(\mathrm{pH} 3.0), 32 \mathrm{mM}$ azure $\mathrm{B}, 1 \mathrm{mM}$ hydrogen peroxide and culture filtrate. The mixture is incubated for $10 \mathrm{~min}$ at $30^{\circ} \mathrm{C}$. The reaction was initiated by adding hydrogen peroxide and absorbance is immediately measured at $651 \mathrm{~nm}$ in one-minute intervals after addition of $\mathrm{H}_{2} \mathrm{O}_{2}$. One unit of enzyme activity is expressed as decrease in absorbance of 0.1 units per minute.

\subsection{Data Analysis}

All the experiments were performed in triplicates and the lignin peroxidase activities were represented as arithmetic mean \pm standard deviation.

\section{Results and Discussion}

\subsection{Identification}

The fungal colony of ANF238 was olivaceous-black in color with white margins (Figure 1(A)). Conidiophores were septate, mostly branched, medium brown and smooth walled. Dictyoconidia with up to 4-5 transverse and several longitudinal septa are medium brown and smooth walled (Figure 1(B)). Conidia were often present in long branched chains having a short conical or cylindrical beak (Figure $1(\mathrm{C})$ ). On the basis of the morphological characterization, the isolate ANF36 was identified as Alternaria sp. which was further confirmed by molecular characterization.

On molecular characterization, it was identified as Alternaria alternata based on nucleotide homology and phylogenetic analysis (Table 1; Figure 2, 3). It has been submitted to National centre for Biotechnology Information (NCBI) under accession no. KX344071 and strain was assigned as ANF238. Information about other close homologs of the isolate is given in Alignment view Table 1. The optimal tree with the sum of branch length $=0.00350571$ is shown in Figure 2. The confidence probability (multiplied by 100) that the interior branch length is greater than 0 , as estimated using the bootstrap test (500 replicates is shown next to the branches $[32,33]$. The evolutionary distances were computed using the Kimura 2-parameter method [34] and are in the units of the number of base substitutions per site. Codon positions included were $1 \mathrm{st}+2 \mathrm{nd}+3 \mathrm{rd}+$ Noncoding. All positions containing gaps and missing data were eliminated from the dataset (Complete deletion option). There were a total of 572 positions in the final dataset. 


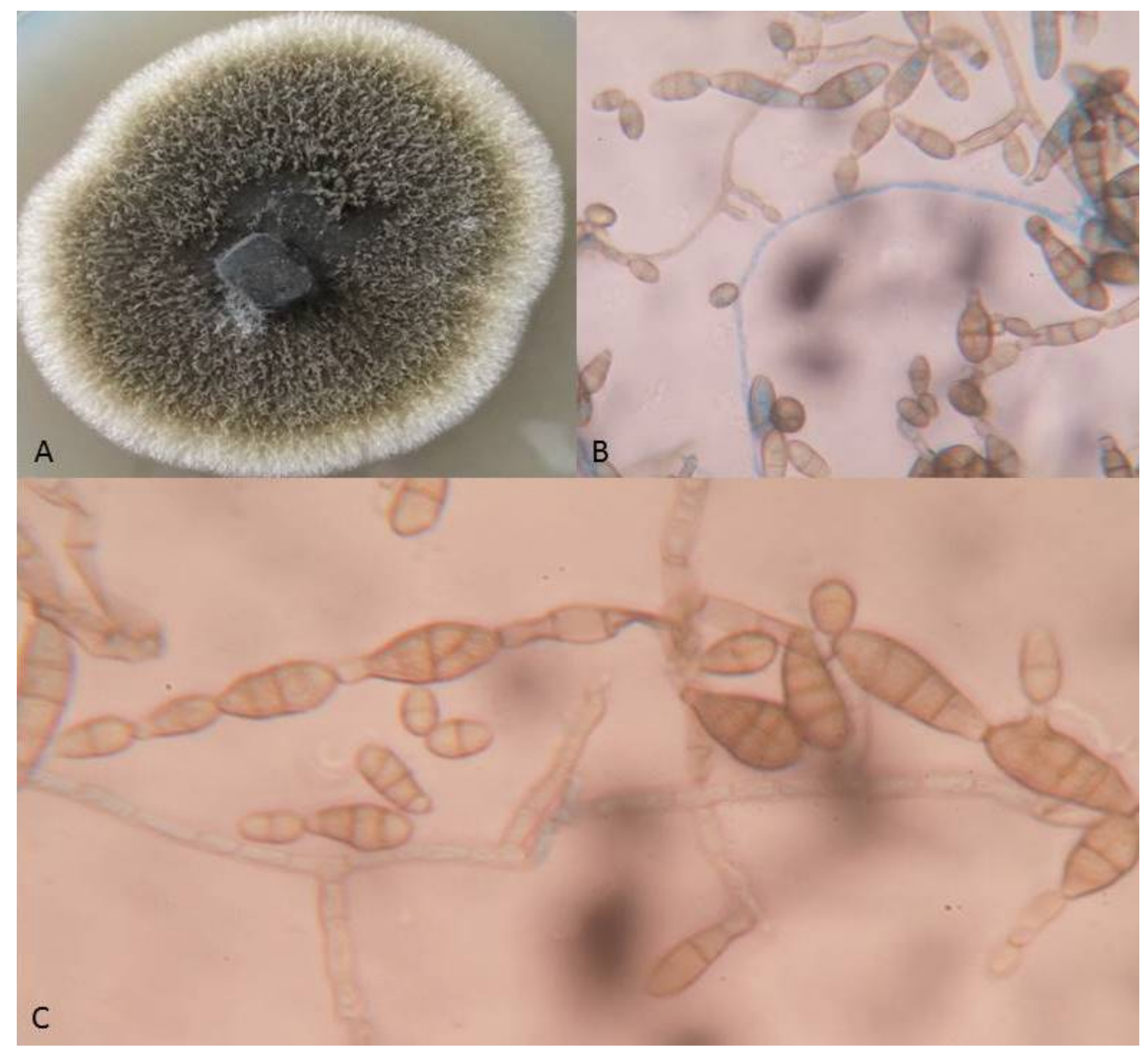

Figure 1. (A.) Colony morphology of Alternaria alternata ANF238 on Potato Dextrose Yeast Agar. (B.) Microscopic view (45X) after Lactophenol cotton blue staining showing dictyoconidia. (C.) Chain of dictyoconidia of Atlernaria alternata ANF238. 
Table 1. Alignment view table showing Sequences producing significant alignments:

\begin{tabular}{|c|c|c|c|c|c|c|}
\hline Description & $\begin{array}{l}\text { Max } \\
\text { score }\end{array}$ & $\begin{array}{l}\text { Total } \\
\text { score }\end{array}$ & $\begin{array}{l}\text { Query } \\
\text { cover }\end{array}$ & $\begin{array}{c}\mathrm{E} \\
\text { value }\end{array}$ & Ident & Accession \\
\hline $\begin{array}{l}\text { Alternaria sp. isolate HP078 } 28 \mathrm{~S} \text { ribosomal RNA } \\
\text { gene, partial sequence }\end{array}$ & 1007 & 1007 & $100 \%$ & 0 & $99 \%$ & KT323287.1 \\
\hline $\begin{array}{l}\text { Alternaria sp. isolate HP066 } 28 \mathrm{~S} \text { ribosomal RNA } \\
\text { gene, partial sequence }\end{array}$ & 1007 & 1007 & $100 \%$ & 0 & $99 \%$ & KT323275.1 \\
\hline $\begin{array}{l}\text { Alternaria alternata strain Block_2a 28S large } \\
\text { subunit ribosomal RNA gene, partial sequence }\end{array}$ & 1007 & 1007 & $100 \%$ & 0 & $99 \%$ & KP940477.1 \\
\hline $\begin{array}{l}\text { Uncultured fungus clone OTUL1 large subunit } \\
\text { ribosomal RNA gene, partial sequence }\end{array}$ & 1007 & 1007 & $100 \%$ & 0 & $99 \%$ & KR905937.1 \\
\hline $\begin{array}{l}\text { Alternaria burnsii strain AB-03 internal transcribed } \\
\text { spacer } 1 \text {, partial sequence; } 5.8 \mathrm{~S} \text { ribosomal RNA gene } \\
\text { and internal transcribed spacer } 2 \text {, complete } \\
\text { sequence; and } 28 \mathrm{~S} \text { ribosomal RNA gene, partial } \\
\text { sequence }\end{array}$ & 1007 & 1007 & $100 \%$ & 0 & $99 \%$ & KR604838.1 \\
\hline $\begin{array}{l}\text { Alternaria burnsii strain AB-02 internal transcribed } \\
\text { spacer } 1 \text {, partial sequence; } 5.8 \mathrm{~S} \text { ribosomal RNA gene } \\
\text { and internal transcribed spacer } 2 \text {, complete } \\
\text { sequence; and } 28 \mathrm{~S} \text { ribosomal RNA gene, partial } \\
\text { sequence }\end{array}$ & 1007 & 1007 & $100 \%$ & 0 & $99 \%$ & KR604837.1 \\
\hline $\begin{array}{l}\text { Alternaria burnsii strain AB-01 internal transcribed } \\
\text { spacer } 1 \text {, partial sequence; } 5.8 \mathrm{~S} \text { ribosomal RNA gene } \\
\text { and internal transcribed spacer } 2 \text {, complete } \\
\text { sequence; and } 28 \mathrm{~S} \text { ribosomal RNA gene, partial } \\
\text { sequence }\end{array}$ & 1007 & 1007 & $100 \%$ & 0 & $99 \%$ & KR604836.1 \\
\hline $\begin{array}{l}\text { Alternaria sp. G393 18S ribosomal RNA gene, partial } \\
\text { sequence; internal transcribed spacer } 1,5.8 \mathrm{~S} \\
\text { ribosomal RNA gene, and internal transcribed spacer } \\
2 \text {, complete sequence; and } 28 \mathrm{~S} \text { ribosomal RNA gene, } \\
\text { partial sequence }\end{array}$ & 1007 & 1007 & $100 \%$ & 0 & $99 \%$ & KR094462.1 \\
\hline $\begin{array}{l}\text { Alternaria sp. G387 } 18 \mathrm{~S} \text { ribosomal RNA gene, partial } \\
\text { sequence; internal transcribed spacer } 1,5.8 \mathrm{~S} \\
\text { ribosomal RNA gene, and internal transcribed spacer } \\
2 \text {, complete sequence; and } 28 \mathrm{~S} \text { ribosomal RNA gene, } \\
\text { partial sequence }\end{array}$ & 1007 & 1007 & $100 \%$ & 0 & $99 \%$ & KR094456.1 \\
\hline $\begin{array}{l}\text { Alternaria sp. NT-2015a voucher CulTenn UCR7 18S } \\
\text { ribosomal RNA gene, partial sequence; internal } \\
\text { transcribed spacer 1,5.8S ribosomal RNA gene, and } \\
\text { internal transcribed spacer 2, complete sequence; } \\
\text { and large subunit ribosomal RNA gene, partial } \\
\text { sequence }\end{array}$ & 1007 & 1007 & $100 \%$ & 0 & $99 \%$ & KT462718.1 \\
\hline
\end{tabular}

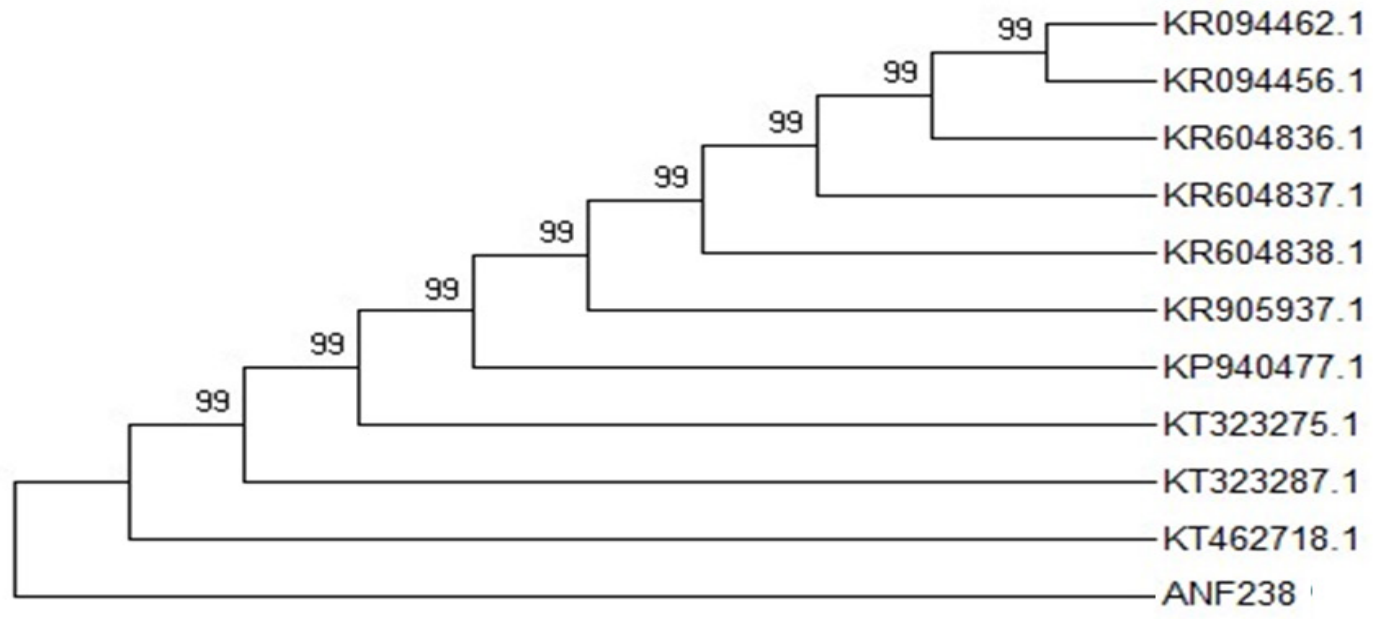

Figure 2. Phylogenetic Tree showing evolutionary relationships of 11 taxa with ANF238 


\begin{tabular}{|c|c|c|c|c|c|c|c|c|c|c|c|}
\hline ANF238 & & 0.0023 & 0.0023 & 0.0023 & 0.0023 & 0.0023 & 0.0023 & 0.0023 & 0.0023 & 0.0023 & 0.0023 \\
\hline KT323287.1 & 0.0035 & & 0.0000 & 0.0000 & 0.0000 & 0.0000 & 0.0000 & 0.0000 & 0.0000 & 0.0000 & 0.0000 \\
\hline 275.1 & 0.0035 & 0.0000 & & 0.0000 & 0.0000 & 0.0000 & 0.0000 & 0.0000 & 0.0000 & 0.0000 & 0.0000 \\
\hline KP94 & 0.0035 & 0.0000 & 0.0000 & & 0.0000 & 0.0000 & 0.0000 & 0.0000 & 0.0000 & 0.0000 & 0.0000 \\
\hline KR9 & 0.0035 & 0.0000 & 0.0000 & 0.0000 & & 0.0000 & 0.0000 & 0.0000 & 0.0000 & 0.0000 & 0.0000 \\
\hline KR6C & 0.0035 & 0.0000 & 0.0000 & 0.0000 & 0.0000 & & 0.0000 & 0.0000 & 0.0000 & 0.0000 & 0.0000 \\
\hline KR60 & 0.0035 & 0.0000 & 0.0000 & 0.0000 & 0.0000 & 0.0000 & & 0.0000 & 0.0000 & 0.0000 & 0.0000 \\
\hline KR604836.1 & 0.0035 & 0.0000 & 0.0000 & 0.0000 & 0.0000 & 0.0000 & 0.0000 & & 0.0000 & 0.0000 & 0.0000 \\
\hline KR094462.1 & 0.0035 & 0.0000 & 0.0000 & 0.0000 & 0.0000 & 0.0000 & 0.0000 & 0.0000 & & 0.0000 & 0.0000 \\
\hline KR094456.1 & 0.0035 & 0.0000 & 0.0000 & 0.0000 & 0.0000 & 0.0000 & 0.0000 & 0.0000 & 0.0000 & & 0.0000 \\
\hline KT462718.1 & 0.0035 & 0.0000 & 0.0000 & 0.0000 & 0.0000 & 0.0000 & 0.0000 & 0.0000 & 0.0000 & 0.0000 & \\
\hline
\end{tabular}

Figure 3. Distance Matrix of ANF238

\subsection{Primary Screening}

Alernaria alternata ANF238 produced a clear zone around the colony (Figure 4) and thus was found to degrade azure $\mathrm{B}$, a clear indication of Lignin peroxidase production. Both azure B and veratryl alcohol are substrates of lignin peroxidase enzyme but azure $B$ has advantage over veratryl alcohol as the action of lignin peroxidase on azure B leads to a visible change in colour by decolourization of azure $B$ from blue to colourless. This feature is usually exploited for isolation and screening of lignin peroxidase producing fungi [35].

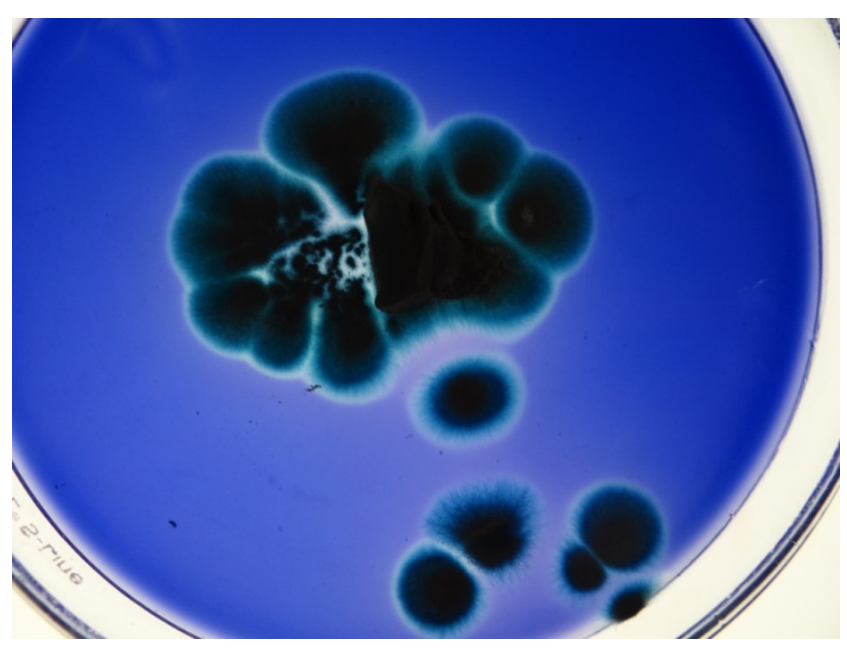

Figure 4. Azure B dye decolorization by Alernaria alternata ANF238

\subsection{Inoculum Preparation}

Maximum fungal growth (in terms of colony diameter) was obtained on Potato Dextrose Yeast Agar $(6.82 \mathrm{~cm})$ followed by Malt Extract Agar $(5.8 \mathrm{~cm})$ and Sabouraud Dextrose Agar $(5.7 \mathrm{~cm})$. Thus, Potato Dextrose Yeast Agar was used for inoculum preparation in further experiments
Table 2. Growth on Different Media

\begin{tabular}{|c|c|c|}
\hline Sr. No. & Name of the growth medium & Colony diameter $(\mathrm{cm})$ \\
\hline 1. & Potato Dextrose Agar (PDA) & 4.06 \\
\hline 2. & $\begin{array}{c}\text { Potato Dextrose Yeast Agar } \\
\text { (PDYA) }\end{array}$ & 6.82 \\
\hline 3. & Czapeck Dox agar (CDA) & 4.36 \\
\hline 4. & Malt Extract Agar (MEA) & 5.8 \\
\hline 5. & $\begin{array}{c}\text { Sabouraud Dextrose Agar } \\
\text { (SDA) }\end{array}$ & 5.7 \\
\hline
\end{tabular}

\subsection{Optimization of Cultural Parameters for Lignin Peroxidase Production}

\subsubsection{Effect of Incubation Time}

LiP activity by Alternaria alternata ANF238 was monitored for a period of 30 days. LiP activity appeared on $4^{\text {th }}$ day of the incubation and there was a gradual increase upto 10 days with maximum activity (3.12U/gram dry substrate) on $10^{\text {th }}$ day of incubation (Figure 5). Maximum increase in LiP activity was between $6^{\text {th }}(1.58 \mathrm{U} /$ gram dry substrate $)$ and $8^{\text {th }}(2.8 \mathrm{U} /$ gram dry substrate $)$ day of incubation. LiP activity kept on decreasing after $10^{\text {th }}$ day of incubation and disappeared on $20^{\text {th }}$ day. There was no LiP activity after that till $24^{\text {th }}$ day, after which very little LiP activity reappeared on 26th day and remained almost constant till $30^{\text {th }}$ day of incubation (data not shown). In a study conducted on lignolytic enzymes production by Dictyoarthrinium synnematicum, LiP activity showed gradual increase up to 30 days of incubation [36]. The present results demonstrated that incubation period remains a determining factor for lignin peroxide activity as the enzyme activity reaches its maximum value in a relatively gradual manner and then falls. The decline in enzyme activity might be result of depletion of macro-and micronutrients in the fermentation medium. 


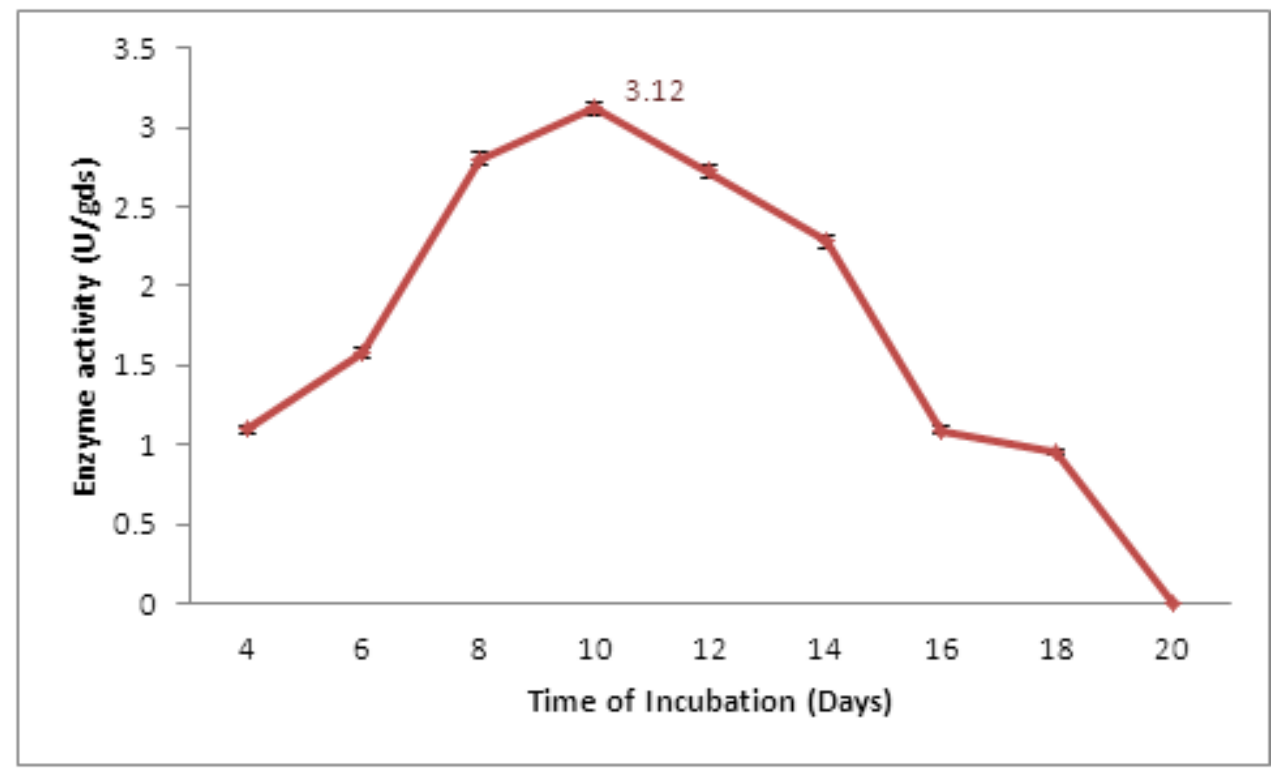

Figure 5. Effect of Time of Incubation on LiP activity

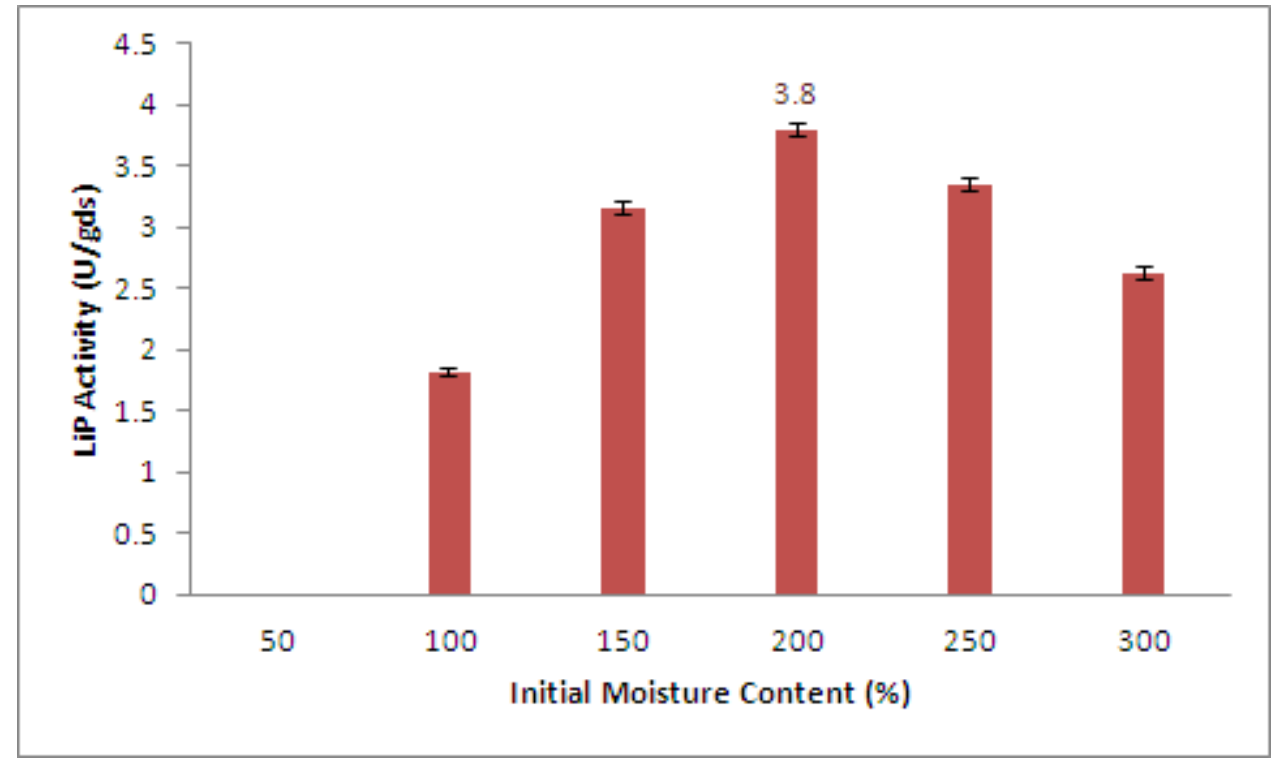

Figure 6. Effect of Initial moisture content on LiP activity

\subsubsection{Effect of Initial moisture content}

LiP activity appeared on attainment of $100 \%(1 \mathrm{ml} / \mathrm{gram}$ dry substrate) initial moisture content and increased consistently till 200\% (2ml/gram dry substrate) at which point LiP activity (3.8 U/gram dry substrate) was highest (Figure 6). On further increasing the initial moisture content, LiP activity decreased suggesting that $200 \%$ moisture content is optimum for maximum LiP production and any increase or decrease in it leads to suppression of LiP production. Increase in initial moisture content beyond an optimum level might reduce the porosity of the substrate, thus limiting the oxygen transfer. Dependency of initial moisture content on substrate used was suggested by a study in which 7-8 ml/g of initial moisture content was found most suitable for LiP production by Phlebia floridensis using wheat straw [37]. However, in another study by M. Kumari [19] $400 \%$ ( 4ml/gram dry substrate) of initial moisture content was used for LiP production by Penicillium citrinum, Fusarium oxysporum and Aspergillus terreus from wheat straw. D. Pant [38] reported LiP activity from $A$. niger and $F$. verticillioides using wheat straw and corn cob at very low initial moisture content of $75 \%$ on using water, molasses, distillery effluent and potato dextrose broth as moistening agents.

\subsubsection{Effect of Carbon Sources}

Effect of supplementation of various carbon sources on LiP production was studied (Figure 7). The addition of carbon sources along with water hyacinth biomass resulted in increase in LiP activity as compared to control containing 
only water hyacinth biomass. Maximum activity of 4.45 $\mathrm{U} /$ gram dry substrate was obtained by the addition of $0.5 \%$ mannitol (Figure 8). Other carbon sources that led to significant increase in LiP activity are lactose and glucose. These results indicate that supplementation with easily metabolizable carbon source leads to better fungal growth, efficient LiP production and lignin degradation of complex lignocellulosic substrates. Use of these carbon sources especially glucose to supplement both synthetic media and lignocellulosic biomass for enhanced production of lignolytic enzymes has been reported in various studies [36, $39,40]$.

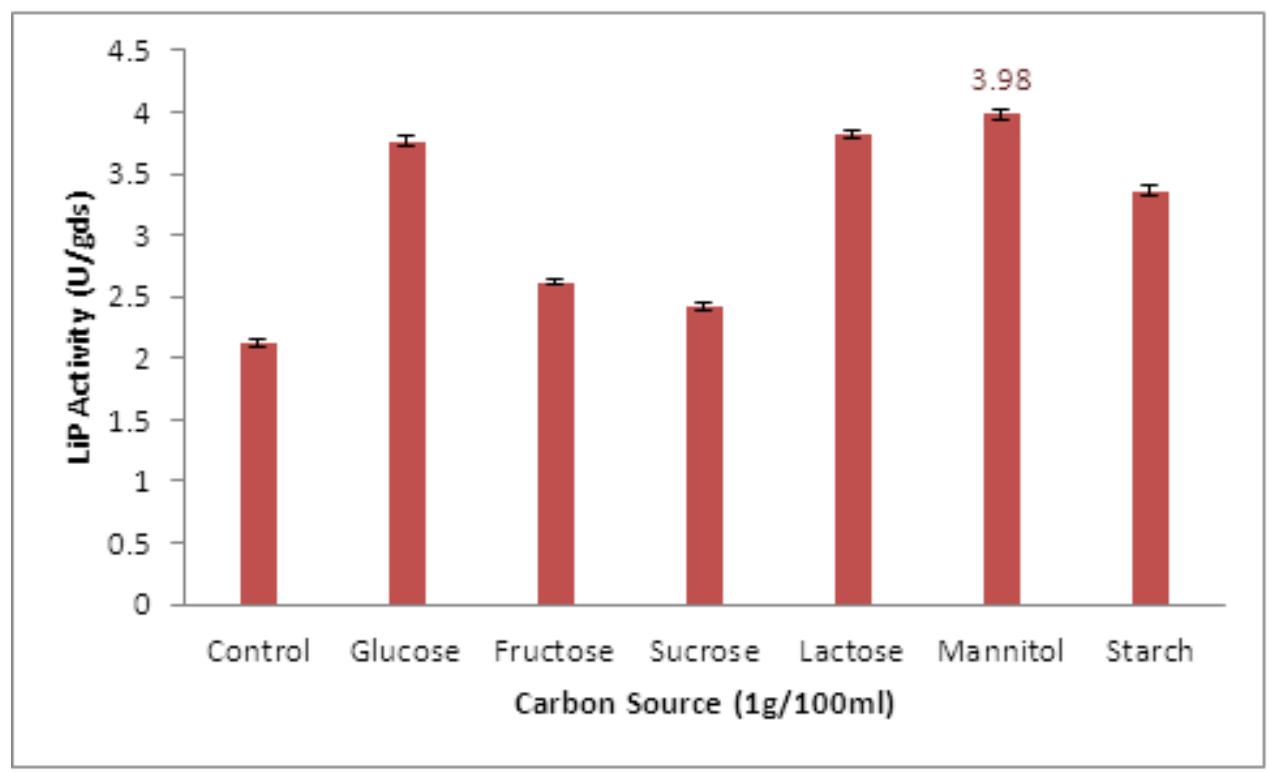

Figure 7. Effect of various Carbon sources on LiP activity

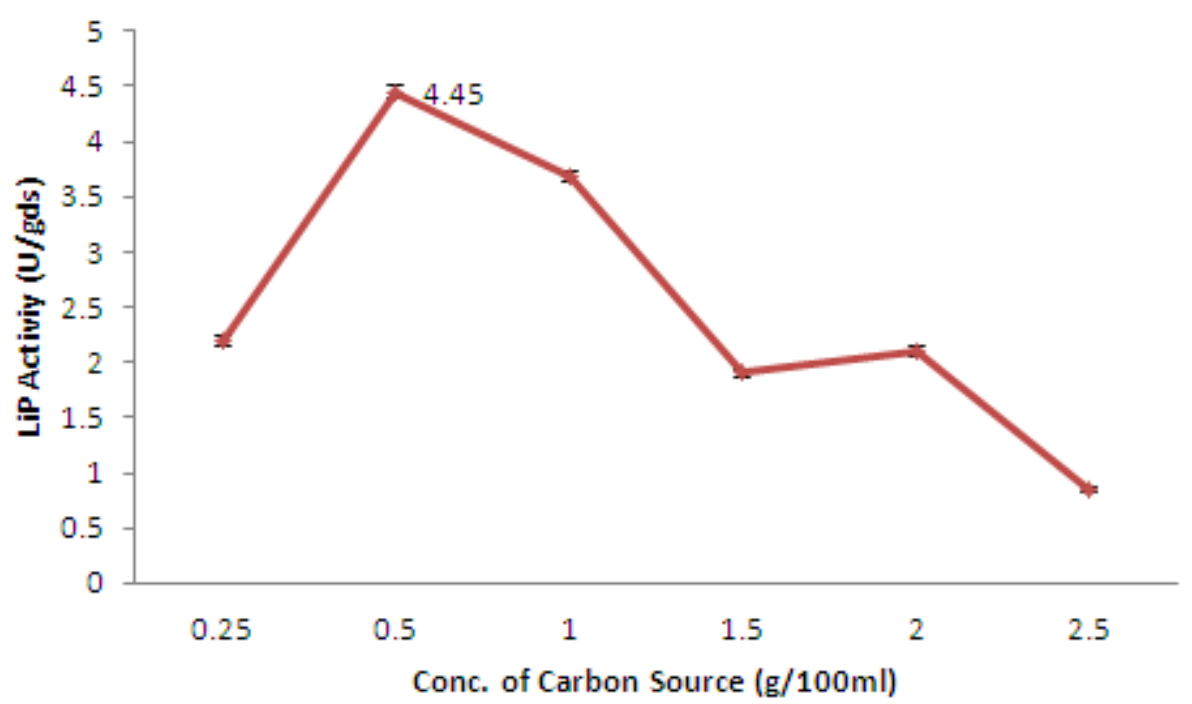

Figure 8. Effect of concentration of mannitol on LiP activity 


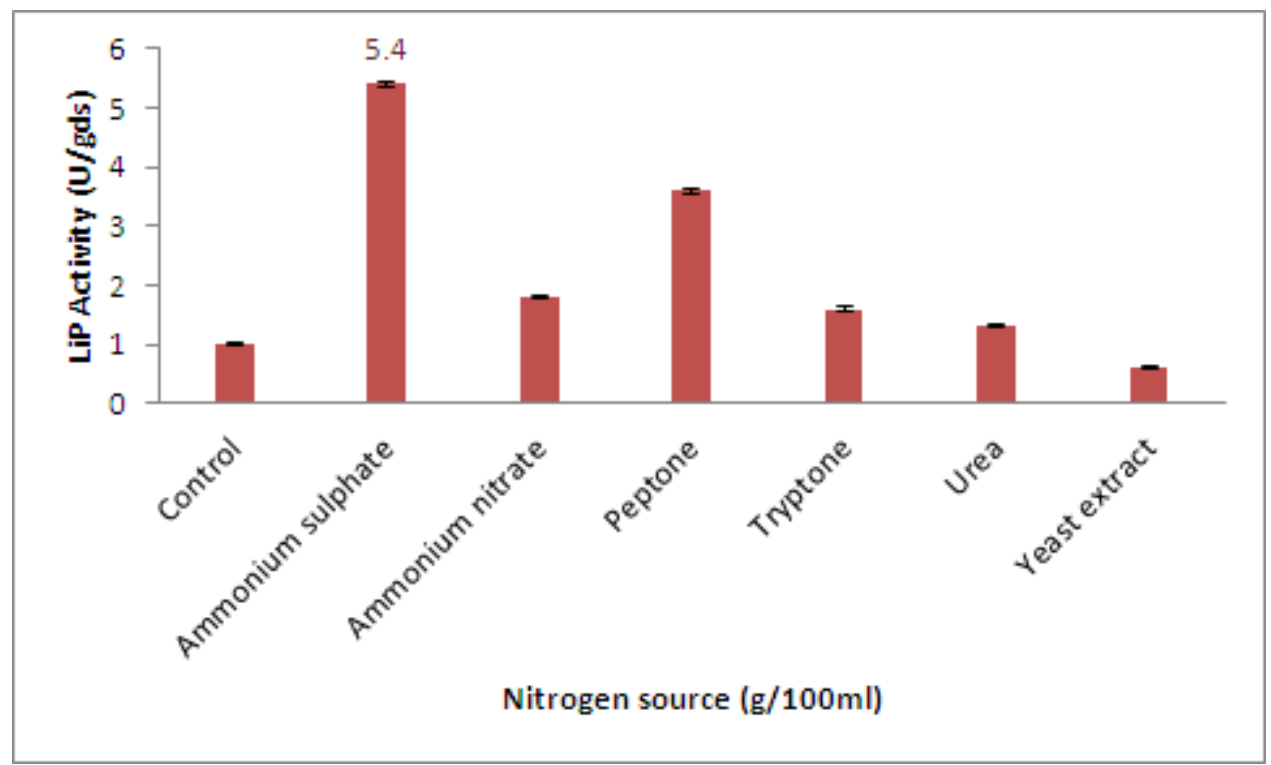

Figure 9. Effect of various Nitrogen sources on LiP activity

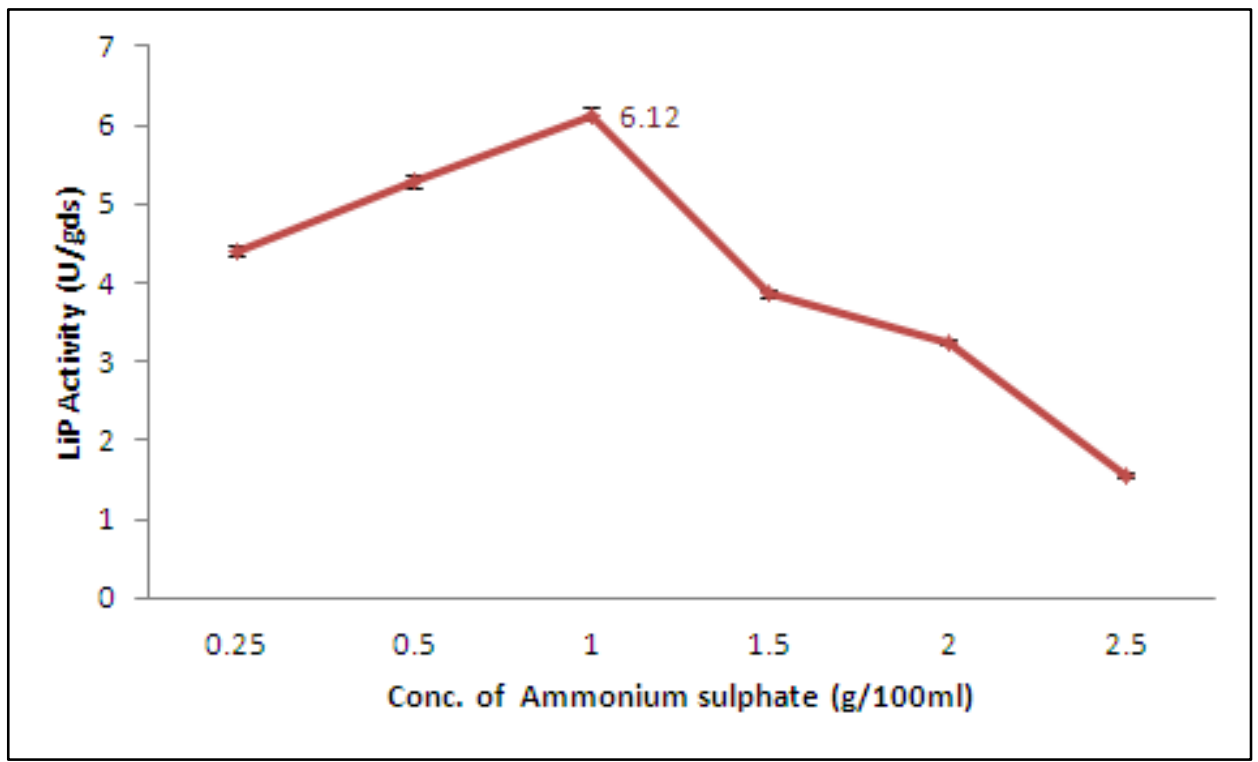

Figure 10. Effect of concentration of Ammonium sulphate on LiP activity

\subsubsection{Effect of Nitrogen source}

It is reported that both the type and concentration of nitrogen source have a profound effect on lignolytic enzyme activity [36, 40]. Six different nitrogen sources were tested for their effect on production of LiP (Figure 9). Highest LiP activity of $5.4 \mathrm{U} /$ gram dry substrate was obtained with inorganic nitrogen source ammonium sulphate at a concentration of $1 \mathrm{~g} / 100 \mathrm{ml}$ (Figure: 10). However, despite being an ammonium salt, ammonium nitrate didn't have much impact on LiP production. These results are in accordance with the findings of I.B. Prasher [36] where highest activity of LiP was obtained with ammonium phosphate whereas no activity was observed in ammonium chloride. Among the complex sources tested, addition of peptone gave the highest LiP activity which was however less than ammonium sulphate. Some studies have contradictory results and have shown that complex sources like peptone have more stimulating effect on LiP activity of Pleurotus ostreatus and Polyporus sanguineus [41, 42]. There are also reports of Lip production in both nitrogen depleting conditions [43] and nitrogen enriched medium [44]. LiP production by Phlebia floridensis was enhanced under nitrogen starvation condition in mineral salt broth [46] while the LiP production was better under nitrogen rich condition using $\mathrm{NH}_{4} \mathrm{Cl}$ when wheat straw was used as a substrate [37]. These variations in results indicate that the effect of various nitrogen sources on lignolytic enzymes activity depend on the species of fungi, type and concentration of nitrogen source and other culture conditions.

\subsubsection{Effect of Inducer}

The role of various inducers in enhancing the activity of 
lignolytic enzymes in white rot basidiomycetes is well known. Thus the effect of various inducers on the production of LiP was observed. Maximum LiP activity of $5.85 \mathrm{U} / \mathrm{gram}$ dry substrate (Figure 11) was observed on supplementation of medium with $\mathrm{MnSO}_{4}$. On optimizing the concentration, a maximum of $7.6 \mathrm{U} /$ gram dry substrate of LiP activity was obtained on addition of $3 \mathrm{mM} \mathrm{MnSO}_{4}$ (Figure 12). This implies that MnSO4 has a significant effect on LiP activity by Alternaria alternata ANF238. These results are in strong disagreement with the findings of P. Bonnarme and T. W. Jeffries [46] who stated that in Mn(II)-free cultures of Phanerochaete chrysosporium, LiP activity appeared earlier and was 2.5 times higher than in cultures grown under the basal conditions. They also reported that effect of $\mathrm{Mn}$ (II) on
LiP production in other basidiomycetes such as Lentinula edodes, Phanerochaete flavido alba, Phanerochaete magnolia, Phellinus pini, Phlebia radiata is inductive at low concentration while repressive at high concentration suggesting that induction or repression by $\mathrm{MnSO}_{4}$ might be both species and concentration dependent. $\mathrm{MnSO}_{4}$ is also known to play a key role in the induction of other extracellular lignolytic enzymes activity including both laccase and manganese peroxidase [47].

Veratryl alcohol was found to be the second best inducer for LiP activity with $4.1 \mathrm{U} /$ gram dry substrate of activity (Figure 6). The inductive effect of veratryl alcohol on LiP activity by Phanerochaete chrysosporium has been well documented in various studies [43, 48].

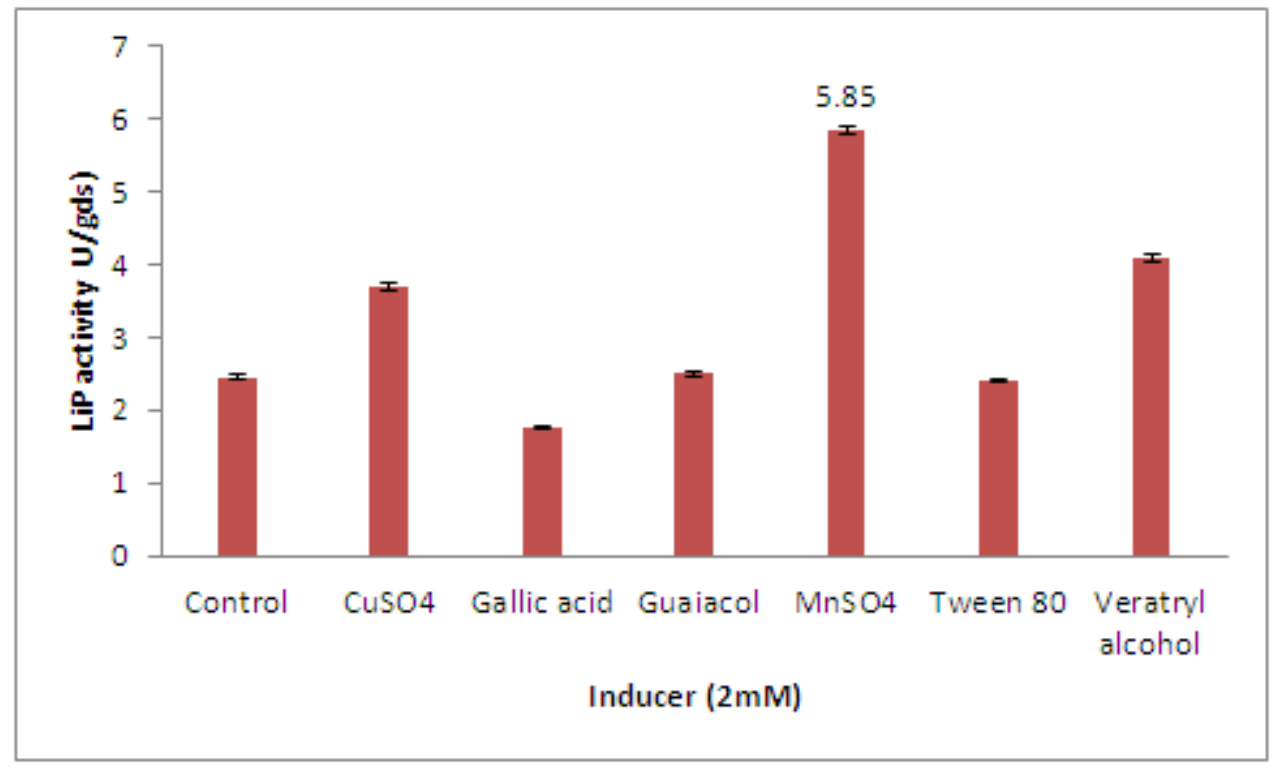

Figure 11. Effect of various Inducers on LiP activity

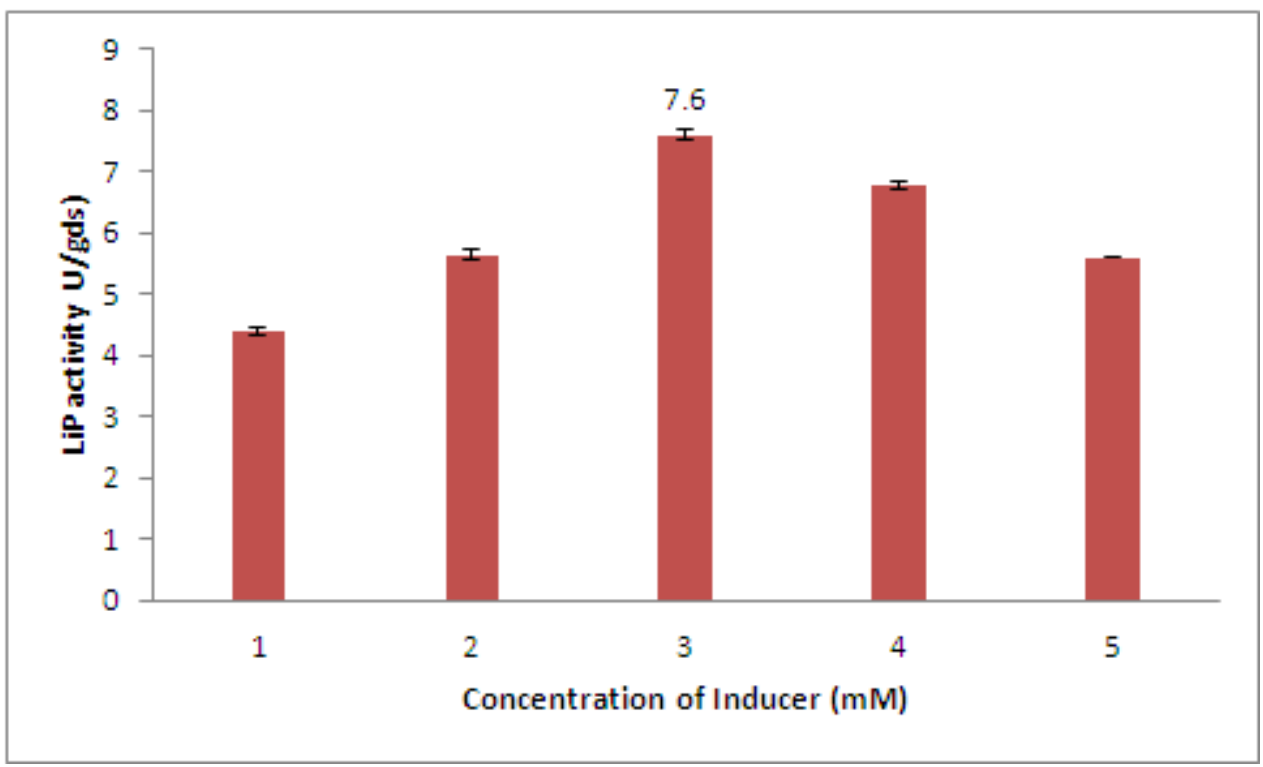

Figure 12. Effect of concentration of $\mathrm{MnSO}_{4}$ on LiP activity 


\section{Conclusions}

The present study illustrates that Alernaria alternata ANF238 isolated from rotten wood sample has the ability to produce lignin peroxidase by using water hyacinth as a cheap and easily available lignocellulosic biomass. Various production parameters were also optimized to increase the production of this enzyme. The final activity obtained on supplementation with $0.5 \%$ mannitol as carbon source, $1 \%$ ammonium sulphate as nitrogen source and $3 \mathrm{mM} \mathrm{MnSO}_{4}$ as inducer was $7.6 \mathrm{U} /$ gram dry substrate. Therefore, Alernaria alternata ANF238 could be considered a promising organism for LiP production, an enzyme that can be exploited in various industrial and biotechnological applications.

\section{REFERENCES}

[1] D.W.S. Wong. Structure and Action Mechanism of Ligninolytic Enzymes, Applied Biochemistry and Biotechnology, vol. 157, pp. 174-209, 2009.

[2] S. Malherbe and T.E. Cloete. Lignocellulosic biodegradation: fundamentals and applications: a review, Environmental Science and Biotechnology, vol. 1, pp. 105-114, 2003.

[3] C. Thurston. The structure and function of fungal laccases, Microbiology, vol. 140, pp. 19-26, 1994.

[4] E.I. Solomon, U.M Sundaram, T.E. Machonkin. Multicopper oxidases and oxigenases, Chemical Reviews, vol. 96, pp. 2563-2605, 1996.

[5] M. Tien and T.K. Kirk. Lignin-degrading enzyme from the hymenomycetes Phanerochaete chrysosporium burds, Science, vol. 221, pp. 661-663, 1983.

[6] K.E. Hammel, K.A. Jensen, M.D. Mozuch, L.L. Landucci, M. Tien, E.A. Pease. Ligninolysis by a purified lignin peroxidase, Journal of Biological Chemistry, vol. 268, pp. 12274-12281, 1993.

[7] C. Eggert, U. Temp, J.F.D. Dean, K.E.L. Eriksson. A fungal metabolite mediates degradation of non-phenolic lignin structures and synthetic lignin by laccase, FEBS Letters, vol. 391, pp. 144-148, 1996.

[8] Y. Shi, L. Chai, C. Tang, Z. Yang, Y. Zheng, Y. Chen. Biochemical investigation of Kraft lignin degradation by Pandoraea sp. B-6 isolated from bamboo slips, Bioprocess and Biosystem Engineering, Vol. 36, pp. 1957-1965, 2013.

[9] S.J. Kim, M. Shoda. Purification and characterization of a novel peroxidase from Geotrichum candidum involved in decolorization of dyes, Applied and Environmental Microbiology, vol. 65, pp. 1029-1035, 1999.

[10] C. Novotny, B. Rawal, M. Bhatt, M. Patel, V. Sasek, H.P. Molitoris. Capacity of Irpex lacteus and Pleurotus ostreatus for decolorization of chemically different dyes, Journal of Biotechnology, vol. 89, pp. 113-122, 2001.

[11] D. Pant, A. Adholeya. Biological approaches for treatment of distillery wastewater: a review, Bioresource Technology, vol.
98, pp. 2321-2334, 2007a.

[12] S.L. Edwards, R. Raag, H. Wariishi, M.H. Gold, T.L. Poulos. Crystal structure of lignin peroxidase, Proceedings of the National Academy of Sciences of the USA, vol. 90, pp. 750754, 1993.

[13] T.L. Poulos, S.L. Edwards, H. Wariishi, M.H. Gold. Crystallographic refinement of lignin peroxidase at $2 \AA$, Journal of Biological Chemistry, vol. 268, pp. 4429-4440, 1993.

[14] V. Singhal and V.S. Rathore, Effects of $\mathrm{Zn} 2+$ and $\mathrm{Cu} 2+$ on growth, lignin degradation and lignolytic enzymes in Phanerochaete chrysosporium, World Journal of Microbiology and Biotechnology, vol. 17, pp. 235-240, 2001.

[15] D. Singh, S. Chen. The white-rot fungus Phanerochaete chrysosporium: conditions for the production of lignin-degrading enzymes, Applied Microbiology and Biotechnology, vol. 81, no. 3, pp. 399-417, 2008

[16] V. Shanmugam, K.D.S. Yadav, Production of lignin peroxidase by Rhizopus nigricans, Indian Journal of Microbiology, vol. 37, pp. 105, 1997.

[17] D.K. Sahoo, R. Gupta. Evaluation of ligninolytic microorganisms for efficient decolorization of a small pulp and paper mill effluent, Process Biochemistry, vol. 40 pp. 1573-1578, 2005

[18] M.P. Shah, G.V. Reddy, R. Banerjee, P.R. Babu, I.L. Kothari. Microbial degradation of banana waste under solid state bioprocessing using two lignocellulolytic fungi (Phylosticta spp. MPS-001 and Aspergillus spp. MPS-002), Process Biochemistry, vol. 40, pp. 445-451, 2005.

[19] M. Kumari, R.S. Yadav, K.D. Yadav. Secretion of lignin peroxidase by Penicillium citrinum, Fusarium oxysporum and Aspergillus terreus, Indian Journal of Experimental Biology, vol. 40, pp. 802-806, 2002.

[20] N. Kanayama, T. Suzuki, K. Kawai. Purification and characterization of an alkaline manganese peroxidase from Aspergillus terreus LD-1, Journal of Bioscience and Bioengineering, vol. 93, pp. 405-410, 2002.

[21] J.R.H. Fernaud, A. Marina, K. Gonzalez, J. Vazquez, M.A. Falcon. Production, partial characterization and mass spectrometric studies of the extracellular laccase activity from Fusarium proliferatum, Applied Microbiology and Biotechnology, vol. 70, pp. 212-221, 2006.

[22] S. Das, A. Ganguly, A. Dey, Y. Ting, P. K. Chatterjee. Characterization of Water Hyacinth biomass and microbial degradation of the biomass under solid state fermentation using a lignocellulotic fungus (Alternaria spp NITDS1), Journal of Chemical, Biological and Physical Sciences, vol. 4, no. 3, pp. 2279-2293, 2014.

[23] A. Sharma, N. K. Aggarwal, A. Saini, A. Yadav. Beyond Biocontrol: Water Hyacinth-Opportunities and Challenges, Journal of Environmental Science and Technology, vol. 9, no. 1, pp. 26-48, 2016.

[24] P.K. Nagadesi, A. Arya. Enzymatic combustion by Lignolytic enzymes of lignicolous fungi, Kathmandu University Journal of Science Engineering and Technology, vol. 9, no. 1, pp 60-67, 2013.

[25] M.C.N. Saparrat, M.J. Martínez, M.N. Cabello, A.M. 
Arambarri. Screening for ligninolytic enzymes in autochthonous fungal strains from Argentina isolated from different substrata, Revista Iberoamericana De Micologia, vol. 19, pp. 181-185, 2002.

[26] A. Tapwal, S. Varghese, U. Kumar, J. Arora. Production of Laccase by Alternaria alternata and Lasiodiplodia theobromae, European Journal of Experimental Biology, vol. 4, no. 4, pp. 196-201, 2014.

[27] A.M. Mabrouk, Z.H. Kheiralla, E.R. Hamed, A.A. Youssry, A.A. Abd El Aty. Screening of some marine-derived fungal isolates for lignin degrading enzymes (LDEs) production, Agriculture and Biology Journal of North America, vol. 1, no. 4, pp. 591-599, 2010.

[28] R.T. Wedding and J.D. Kentrick. Toxicity of M-methyl-dithiocarbamate and methylisocyanate to Rhizoctonia solani, Phytopathology, vol. 49, pp.557-561, 1959.

[29] N. Saitou and M. Nei. The neighbor-joining method: A new method for reconstructing phylogenetic trees, Molecular Biology and Evolution, vol. 4, pp. 406-425, 1987.

[30] K. Tamura, J. Dudley, M. Nei and S. Kumar. MEGA4: Molecular Evolutionary Genetics Analysis (MEGA) software version 4.0., Molecular Biology and Evolution, vol. 24, pp. 1596-1599, 2007.

[31] F.S. Archibald. A new assay for lignin-type peroxidase employing the dye Azure B, Applied and Environmental Microbiology, vol. 58, pp. 3110-3116, 1992.

[32] J. Dopazo. Estimating errors and confidence intervals for branch lengths in phylogenetic trees by a bootstrap approach, Journal of Molecular Evolution, vol. 38 pp. 300-304, 1994.

[33] A. Rzhetsky and M. Nei. A simple method for estimating and testing minimum evolution trees, Molecular Biology and Evolution, vol. 9, pp. 945-967, 1992.

[34] M. Kimura. A simple method for estimating evolutionary rate of base substitutions through comparative studies of nucleotide sequences, Journal of Molecular Evolution, vol. 16, pp. 111-120, 1980.

[35] P. Reanprayoon and W. Pathomsiriwong. Tropical soil fungi producing cellulase and related enzymes in biodegradation, Journal of applied sciences, vol. 12, no. 8, pp. 1909-1916, 2012.

[36] I.B. Prasher, R. Chauhan. Effect of Carbon and Nitrogen Sources on the Growth, Reproduction and Ligninolytic Enzymes Activity of Dictyoarthrinium Synnematicum, Advances in Zoology and Botany, vol. 3, no. 2, pp. 24-30, 2015.

[37] R.K. Sharma and D.S. Arora. Production of lignocellulosic enzymes and enhancement of invitro digestibility during solid state fermentation of wheat straw by Phlebia floridensis,
Bioresource Technology, vol. 101, pp. 9248-9253, 2010.

[38] D. Pant, A. Adholeya. Enhanced production of ligninolytic enzymes and decolorization of molasses distillery wastewater by fungi under solid state fermentation, Biodegradation, vol. 18, pp. 647-659, 2007.

[39] E.E.J. Kaal, J.A. Field, and T.W. Joyce. Increasing ligninolytic enzymatic activities in several white rot basidiomycetes by nutrient sufficient media, Bioresource Technology, vol. 59, pp. 133-139, 1995.

[40] V. Sivakami, B. Ramachandran, J. Srivathsan, G. Kesavaperumal , S. Benila, K. D. J. Mukesh. Production and optimization of laccase and lignin peroxidase by newly isolated Pleurotus ostreatus LIG19, Journal of Microbiology and Biotechnology Research, vol. 2, no. 6, pp.875-881, 2012.

[41] N. Mikiashvili, S.P. Wasser, E. Nevo, V. Elisashvili. Effects of carbon and nitrogen sources on Pleurotus ostreatus ligninolytic enzyme activity, World Journal of Microbiology and Biotechnology, vol. 22, pp. 999-1002, 2006.

[42] P.K. Bajwa, D.S. Arora. Comparative production of ligninolytic enzymes by Phanerochaete chrysosporium and Polyporus sanguineus, Canadian Journal of Microbiology, vol. 55, pp. 1397-1402, 2009.

[43] H. Podgronik, A. Podgronik, P. Milavec, A. Perdih. The effect of agitation and nitrogen concentration on lignin peroxidase (LiP) isoform composition during fermentation of Phanerochaete chrysosporium, Journal of Biotechnology, vol. 88, pp. 173-176, 2001.

[44] E.E.J. Kaal, E. Jong and J.A. Field. Stimulation of Ligninolytic Peroxidase Activity by Nitrogen Nutrients in the White Rot Fungus sp. Bjerkandera Strain BOS55, Applied Journal of Environmental Microbiology, vol. 59, no. 12, pp. 4031-4036, 1993.

[45] D.S. Arora, P.K. Gill. Production of ligninolytic enzymes by Phlebia floridensis, World Journal of Microbiology and Biotechnology, vol. 21, pp. 1021-1028, 2005.

[46] P. Bonnarme and T.W. Jeffries. Mn(II) Regulation of Lignin Peroxidases and Manganese-Dependent Peroxidases from Lignin-Degrading White Rot Fungi, Applied Journal of Environmental Microbiology, vol. 56, no. 1, pp. 210-217, 1990.

[47] M. Akpinar and R.O. Urek. Production of ligninolytic enzymes by solid state fermentation using Pleurotus eryngii, Preparative Biochemistry \& Biotechnology, vol. 42, pp. 582$597,2012$.

[48] M.A. Khiyami, A.L. Pometto, W.J. Kennedy. Ligninolytic enzyme production by Phanerochaete chrysosporium in plastic composite support biofilm stirred tank bioreactors, Journal of Agricultural and Food Chemistry, vol. 8, pp. 1693$1698,2006$. 